\title{
Study of Environmental Carrying Capacity in the Development of Kayangan Api Tourism Object, Bojonegoro Regency
}

\author{
$1^{\text {st }}$ Nailul Insani \\ Departement of Geography \\ State University of Malang \\ Malang, Indonesia \\ nailul.insani.fis@um.ac.id \\ $2^{\text {nd }}$ Dyah Rina Syafitri \\ Departement of Geography \\ State University of Malang \\ Malang, Indonesia \\ dyahrina1807@gmail.com
}

\author{
$3^{\text {rd }}$ Elia Vetty K Ningrum \\ Departement of Geography \\ State University of Malang \\ Malang, Indonesia \\ eliavetty2@gmail.com \\ $4^{\text {th }}$ Hanifa A Mufid \\ Departement of Geography \\ State University of Malang \\ Malang, Indonesia \\ hanifaahmadmufid@gmail.com
}

\begin{abstract}
The progress of the tourism industry in an area is very dependent on the potential, management and improvement of the utilization of Tourism Destination Areas (DTW). The existence of the potential of tourism has an impact on the increase and the number of visitors and mass tourists. One of the tourist destinations in Bojonegoro Regency, East Java is the Kayangan Api tourist attraction. The tourism object of Kayangan Api is an excellent tourism icon in Bojonegoro Regency. This tourism object is located in Sendangharjo Village, Ngasem District, Bojonegoro Regency, East Java. The Kayangan Api tourism object is located in a protected forest area, so that its management is a collaboration between the government, namely the Culture and Tourism Office, the Perhutani and involving the local community. The number of tourists coming to the Kayangan Api tourist attraction always increases every year. The manager has also continued to develop efforts both physically and non-physically. This study aims to (1) Determine the carrying capacity of the environment in the Kayangan Api tourist attraction (2) Analyze the development of a Kayangan Api tourist attraction. The method used is a quantitative descriptive method by using the Regional Caarring Capacity Analysis (DDK), SWOT and spatial analysis techniques to determine the existing potential. Data is obtained through interviews and field observations. The result show types of activities identified include outbound, historical tours, playgrounds, ruwatan ceremonies, jumenengan ceremonies and waranggono graduation ceremonies. Outbound activity has the highest DDK value than other activities, namely 1200 visitors because the area provided for outbound is still quite large at $500 \mathrm{~m} 2$. Identification of potential as a dominance of tourist activities to determine the
\end{abstract}

type of development that is applied specifically to maximize the capacity of tourists.

Keywords: Regional Carrying Capacity, Kayangan Api, tourism development

\section{INTRODUCTION}

United Nation World Tourism Organizations (UNWTO) refer to tourism as the leading sector or Leading Sector which plays an important role in the development of the country and the improvement of people's welfare [1]. Not only that, the UN organization engaged in tourism reported that tourism contributed $9 \%$ of total world GDP and fulfilled $6 \%$ of total world export value or US \$ 1.5 trillion [2]. This is evidenced by the value of destination visits throughout the world in 2017 reaching 1,323 million international tourists, around 84 million exceeding 2016 visit numbers [3]. Likewise, the tourism sector in Indonesia, the tourism sector has become a key driver as well as a key driver for the socio-economic growth of a country through the creation of jobs and business opportunities, export earnings in tourism, and infrastructure development. Therefore, Indonesia lifted tourism as a leading sector that received support from various other sectors [4].

Indonesian tourism contributed $10 \%$ of national GDP, with the highest nominal in ASEAN in 2015, higher than in other industries such as agriculture, automotive manufacturing and mining. National GDP from tourism continues to grow $4.8 \%$ with an upward trend of $6.9 \%$. Further explanation is known that 
tourism activities in which there are supporting elements such as administration, tourism facilities, quality control of attraction and the implementation of marketing systems. Kayanga Api tourism object has the potential to be an activator of economic activity and support the welfare of the Bojonegoro people. This is evidenced by the number of fire visitations which reached 65,519 visits in 2017 [10]. Where this uniqueness has become a great potential for the development of Kayangan Api tourism destination, Bojonegoro district. Along with the increasing number of tourists who come to the Kayangan Api tourist area, it is necessary to calculate the Tourism Carrying Capacity (DDK). Calculation of the carrying capacity of this area is conducted to determine the maximum number of visitors who come to the Kayangan Api tourist area at one time and does not endanger the environment or the ecosystem. The objectives of this research are (1) calculation the carrying capacity of the tourism area of the heavenly tourism, (2) analyze the development of the Kayangan Api tourist attraction.

\section{METHOD}

This research was conducted in the Attraction of heaven Fire, Bojonegoro Regency, East Java. The method used in this research is quantitative descriptive. Data acquisition is based on calculations and supported by interviews, spatial observations by researchers to respondents of the Kayangan api tourism area obtained through interviews with various sources including traders, visitors and managers to obtain interrelated answers. Here are the methods used by the author in determining the carrying capacity of the region as well as tourism development strategies in Kayangan Api.

\section{A. Regional Carrying Capacity (DDK)}

The DDK method is used to determine the capacity and direction of the sector that must be developed. DDK is the maximum ability of an area to be able to accommodate a number of visitors at a certain time without causing disturbance to nature and humans. Formula for carrying capacity of the region [11]. The following is the formula for applying the DDK method [12]:

$$
\mathrm{DDK}=K \frac{L p}{L t} \times \frac{W t}{W p}
$$

district which is part of the Cepu Block, which is one of the largest petroleum sources in Indonesia or better known as the diapirism zone in the developing zone [7]. In addition, the location of this tourist destination is a complex of respected cultural sites and is closely related to the trust of the local community. Supported by its location in the middle of a protected forest, this destination is in great demand both as a type of historical education tourism and even spiritual tourism.

During this time, the management system of the Fire Shadow destination is directly carried out by the government through the Department of Culture and Tourism, Perhutani and the empowerment of the local community [8]. The Culture and Tourism Office acts as an element of planning, operational policy making, controlling and organizing tourism destinations [9]. The organizing activities are in the form of procurement of

$$
\begin{array}{ll}
\mathrm{K} & =\text { Jumlah umum pengunjung yang bekegiatan } \\
\mathrm{Wp} & =\text { Waktu yang dibutuhkan pengunjung } \\
\mathrm{Wt} & =\text { Durasi operasional tempat wisata } \\
\mathrm{Lt} & =\text { Luas area unit kegiatan } \\
\mathrm{Lp} & =\text { Luas area yang dapt dimanfatkan untuk kegiatan tertentu }
\end{array}
$$

\section{B. SWOT Analysis}

SWOT analysis is a method of identifying various factors systematically to formulate a company's strategy. This analysis is based on logic that can maximize strengths and opportunities, but simultaneously minimize weaknesses (Weaknesses) and threats (Threats) [13]. Analysis of the development of Fire Shadow tourism using the SWOT Matrix with IFAS and EFAS 
phenomenon never goes out even in the rainy season so it is often called an eternal fire. This natural phenomenon is related to the geological conditions in the Kayangan Api area, where the condition of karst rock domination as the main constituent material in the region which then meets with tectonic activity in the form of plates and rocks in the form of faults is one of the factors in the emergence of natural gas [16].

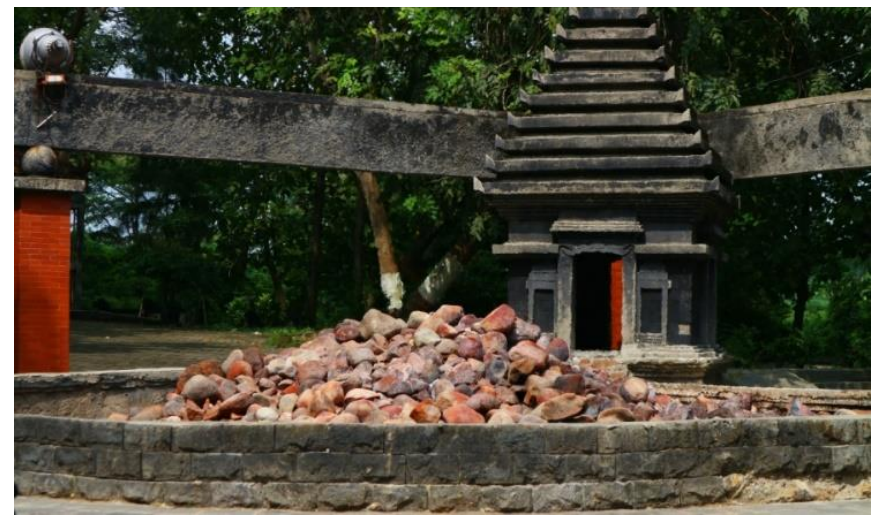

Fig. 2. Bursts of Natural Gas as a Result of Tectonic Activities in the Kayangan Api Tourism Area

Not only the physical potential of the area but there is also a historical value that exists in these destinations forming a unique pattern in Kayangan Api tourism activities. In terms of history and culture, the existence of Kayangan Api attractions can be traced since the days of the Majapahit kingdom. In that era, the source of fire at the location of this tourist attraction is often used for special purposes relating to the field of weaponry as a means of making heirlooms as well as a means of religious ceremony for the local community. Based on the story that developed in the community, the existence of the source of fire that emerged was used by the iron pande in the past to purify the heirloom that he had successfully made. This unique physical and historical factor supports the Kayangan api attraction as a complete package tour destination.

As a tourist attraction that offers a complete package of history and nature, this attraction is increasingly crowded with tourists. The presence of many tourists can be a benefit for the surrounding community in improving welfare through trade and services related to tourism activities. On the other hand a large number of tourists can be a threat to the natural environment around attractions. For this reason it is important to know the carrying capacity of the tourist attraction area, so that the maximum number of tourists that can be accompanied in the Kayangan Api tourist attraction can be known at one time. Calculation of Carrying Capacity of the Area (DDK) in the Kayangan api area is presented in the table below. 
TABLE I. ACTIVITIES AND VALUE OF DDK KAYANGAN API BOJONEGORO

\begin{tabular}{|l|c|c|c|c|c|c|}
\hline \multicolumn{1}{|c|}{ Kegiatan } & $\mathbf{K}$ & $\begin{array}{c}\mathbf{W p} \\
\text { (hour) }\end{array}$ & $\begin{array}{c}\text { Wt } \\
\text { (hour) }\end{array}$ & Lt & Lp & DDK (Visitors) \\
\hline Outbond & 50 & 5 & 24 & $100 \mathrm{~m}^{2}$ & $500 \mathrm{~m}^{2}$ & 1.200 \\
\hline Historical tour & 1 & 2 & 24 & $200 \mathrm{~m}^{2}$ & $500 \mathrm{~m}^{2}$ & 30 \\
\hline Playground & 1 & 2 & 24 & $25 \mathrm{~m}^{2}$ & $50 \mathrm{~m}^{2}$ & 48 \\
\hline Ruwatan traditional ceremony & 1 & 6 & 24 & $50 \mathrm{~m}^{2}$ & $100 \mathrm{~m}^{2}$ & 8 \\
\hline Jumenengan traditional ceremony & 1 & 6 & 24 & $50 \mathrm{~m}^{2}$ & $100 \mathrm{~m}^{2}$ & 8 \\
\hline Waranggono Graduation ceremony & 20 & 3 & 24 & $50 \mathrm{~m}^{2}$ & $100 \mathrm{~m}^{2}$ & 320 \\
\hline
\end{tabular}

Variable K represents the number of visitors engaged in each type of activity. As in the outbound activities and Graduation Waranggono Ceremony where these activities are generally carried out by certain groups. Unlike the case with other activities which are generally only carried out by certain individuals. These conditions represent the purpose and special activities undertaken by visitors. These objectives will utilize part of the space as a tourism sector or as a sector of cultural preservation through certain ritual activities. The $\mathrm{Wp}$ variable represents the average time required for each visitor to fulfill his satisfaction in a certain type of activity. In each activity that can be seen in the table, each visitor has a different allocation of time needed to optimize the utilization of available locations with information on the duration of the operational place on the variable Wt. It was also viewed from the type of activity, the purpose of the activity, and the procession carried out by visitors in the Kayangan Api Tourism area.

The next variable is Lt which represents the area in each activity unit. This means that these variables indicate the extent of the area used optimally in certain types of activities. This can be realized by maximizing the construction of facilities and infrastructure so that the types of activities carried out by visitors can be maximized in the area. For example in certain types of activities such as Ruwatan Ceremony, Jumenengan Ceremony and Waranggono Graduation Ceremony are conducted in certain sectors that are not related to other types of tourism activities. This was realized by the existence of special buildings such as a pavilion and several lanes which were indeed devoted to the perpetrators of the ceremony. The Lt variable has a close relationship with the $L p$ variable. Where the $L p$ variable represents the area that can be utilized for certain types of activities. That is, the variable Lp indicates the area of land that can be used for certain types of activities but there is no maximum utilization or is still in the form of vacant land. This condition is generally related to the pattern of regional development that is currently being planned, especially in the area of expansion.

Based on table 3.1, the types of activities identified include outbound, historical tours, playgrounds, ruwatan ceremonies, jumenengan ceremonies and waranggono graduation ceremonies. Outbound activity has the highest DDK value than other activities, namely 1200 visitors because the area provided for outbound is still quite large at $500 \mathrm{~m} 2$. Outbound activities are usually conducted in the area behind the Kayangan Api tourist attraction, adjacent to the agricultural area. The area in its development planning will experience a change of location in accordance with the purpose of developing the area expansion. In addition, the historical and cultural context is an attraction in the Kayangan Api tourist area. These activities are generally spiritual facilities and a series of special activities related to traditions or processions with specific objectives. One of the tourist attractions in the form of a center of fire that is used by visitors, is the main media in the implementation of these spiritual activities. The relationship between physical and historical potential makes the main factor in the development of tourism, so it is necessary to optimize the utilization of these potentials.

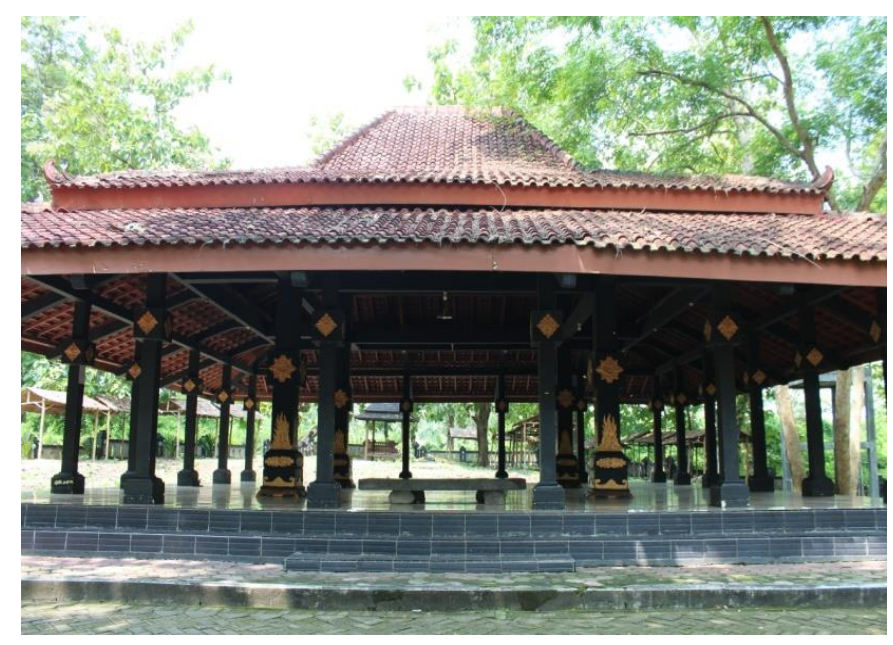

Fig. 3. Attraction facilities such as Pendopo Building

Based on interviews with managers, the activities of expanding the Kayangan Api tourism area have indeed become the main focus because currently the number of tourist visits to Kayangan Api has increased significantly and the existing tourism activities are increasingly diverse. But it is not balanced with the improvement of infrastructure quality. This happens because there is no clear pattern of expansion as to what will be done. The lack of clarity is due to the location of Kayangan Api Tourism located in Perhutani's protected forest area and needs to obtain permission and special supervision in its development activities. On the other hand this increasingly intensive 
increase the attractiveness of the Kayangan Api tourist area, especially towards the historical and cultural appeal.

In determining the direction of tourism development carried out by the SWOT method with IFAS and EFAS analysis techniques as a guide for determining the development priority quadrant. SWOT analysis is an efficient structured planning method used in the case of strategic planning, to identify project potentials and priorities for meeting strategy development. IFOT and EFAS SWOT analysis results can be seen in Tables 3 and 4.

TABLE II. INTERNAL FACTORS (STRENGTHS AND WEAKNESSES)

\begin{tabular}{|c|c|c|c|}
\hline Strenghts & Quality (a) & Rating (b) & Score $(\mathbf{a} * \mathbf{b})$ \\
\hline 1. Stategic location. & 0,13 & 4 & 0,52 \\
\hline 2. Easy accessibility. & 0,14 & 4 & 0,56 \\
\hline 3. Clean from rubbish. & 0,06 & 2 & 0,12 \\
\hline 4. Good facilities and quite complete. & 0,10 & 3 & 0,30 \\
\hline 5. Cheap ticket prices. & 0,10 & 3 & 0,30 \\
\hline 6. The water used comes from spring sources (does not contain chlorine). & 0,12 & 4 & 0,48 \\
\hline 7. Large parking area & 0,09 & 3 & 0,27 \\
\hline 8. Beautiful eternal fire panorama & 0,08 & 3 & 0,24 \\
\hline 9. The condition of the tourist attraction is still natural & 0,08 & 3 & 0,24 \\
\hline 10. Government support for the development of tourism objects. & 0,10 & 3 & 0,30 \\
\hline Total & 1 & & $\mathbf{3 , 3 3}$ \\
\hline Weakness & Quality (a) & Rating (b) & Score $(\mathbf{a} * \mathbf{b})$ \\
\hline 1. Lack of information for visitors regarding tourist activities at the location. & 0,09 & 4 & 0,36 \\
\hline 2. Monkeys that are left free can disturb tourists. & 0,09 & 4 & 0,36 \\
\hline 3. Lots of monkey dung scattered. & 0,07 & 4 & 0,28 \\
\hline 4. Many facilities are damaged and lack of maintenance. & 0,11 & 2 & 0,22 \\
\hline 5. Many vehicles are closed or not used. & 0,11 & 2 & 0,22 \\
\hline 6. Security is not guaranteed. & 0,10 & 3 & 0,30 \\
\hline 7. Lack of supervision of visitors. & 0,11 & 2 & 0,22 \\
\hline 8. The front view of the tourist attractions is less attractive. & 0,10 & 3 & 0,30 \\
\hline 9. Lack of promotion. & 0,09 & 4 & 0,36 \\
\hline 10. Spiritual activities and tourism in general are not yet separate. & 0,12 & 1 & 0,12 \\
\hline Total & 1 & & 2,74 \\
\hline $\mathrm{X}=$ Strengths - Weakness & & & $\mathbf{0 , 5 9}$ \\
\hline
\end{tabular}

The value of $\mathrm{X}$ resulting from the difference between weakness and strength has a value of 0.59 . With the acquisition of value $X$, it can be described that the Fire Shadow has good potential, but there are still some weaknesses that still must be considered

TABLE III. EXTERNAL FACTORS (OPPORTUNITIES AND THREATS)

\begin{tabular}{|c|c|c|c|}
\hline Opportunities & Bobot (a) & Rating (b) & Skor $(\mathbf{a} * \mathbf{b})$ \\
\hline 1. Close to other tourist locations & 0,30 & 4 & 1,2 \\
\hline 2. Kebutuhan lokasi studi geologi bagi pelajar dan mahasiswa. & 0,20 & 3 & 0,60 \\
\hline 3. Close to the center of Bojonegoro Regency & 0,12 & 2 & 0,24 \\
\hline 4. Trend gerakan pelestarian lingkungan & 0,13 & 3 & 0,39 \\
\hline 5. Local government policies related to tourism & 0,25 & 4 & 1 \\
\hline Total & 1 & & 3,43 \\
\hline \multicolumn{4}{|l|}{ Threat } \\
\hline 1. Disaster & 0,30 & 1 & 0,30 \\
\hline 2. Increasing the number of monkey populations. & 0,14 & 3 & 0,42 \\
\hline $\begin{array}{l}\text { 3. The surrounding community is ignorant of the existence of Kayangan Api } \\
\text { tourism. }\end{array}$ & 0,15 & 3 & 0,45 \\
\hline 4. Competition with other attractions & 0,25 & 2 & 0,50 \\
\hline 5. Lack of facilities caused by monkeys & 0,16 & 3 & 0,48 \\
\hline \multicolumn{4}{|l|}{ Total } \\
\hline \multirow[t]{2}{*}{$\mathbf{Y}=$ Peluang - Ancaman } & 1 & & 2,15 \\
\hline & & & 1,28 \\
\hline
\end{tabular}


The $\mathrm{Y}$ value resulting from the difference between opportunity and threat has a value of 1.28. With the acquisition of these values, it can be concluded that the Kayangan Api tourist attraction has a good opportunity, but still needs to be aware of several threats that have the potential to interfere with existing development. With both IFAS and EFAS values, the results of determining the development priority quadrant are as follows (fig 4).

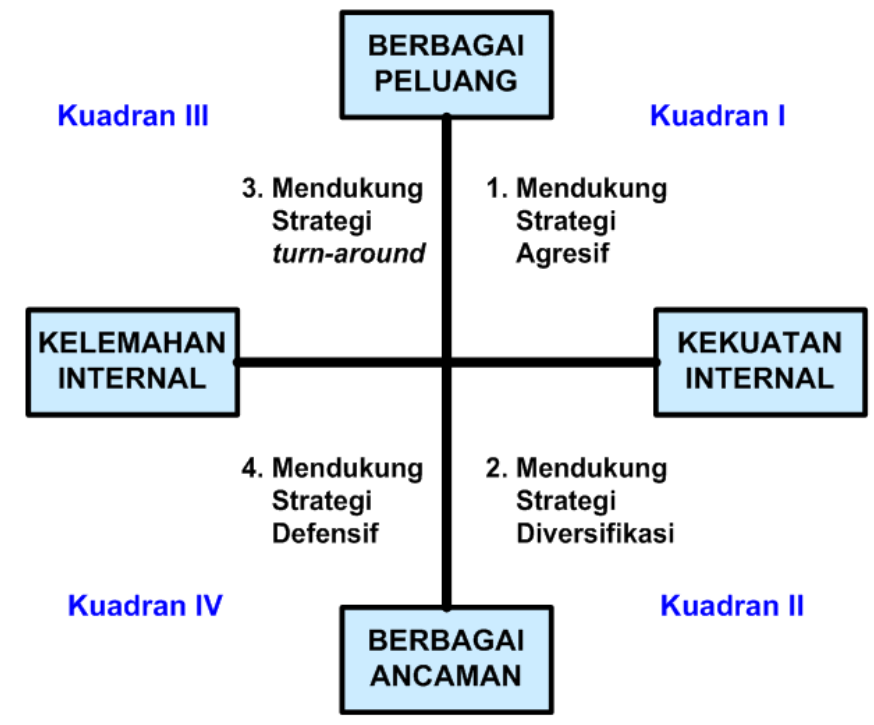

Fig. 4. The results of determining the priority development quadrant on the SWOT method of IFAS \& EFAS analysis

Based on the SWOT analysis diagram, the indicator occupies the area in quadrant I which means that development activities can be conducted optimally through internal strengths and various opportunities arising from the external. The potential is in the form of the utilization of tourist attractions, namely the existence of natural gas and fire sources. The condition of environmental preservation in the form of protected forests can also be used as an identity or attraction, especially for the convenience of visitors. The development is devoted to optimizing the capacity, and adding facilities by expanding the area according to the plan held by the manager. In line with this, the Kayangan Api tourist attraction also needs to get more attention from the government in developing, monitoring, evaluating and improving environmentally friendly tourist facilities which are packaged according to local wisdom of the local culture to preserve the main potential in the form of an eternal fire source.

\section{CONCLUSION}

The development of tourism in the world encourages Indonesia to also develop the existing tourism potential. As one of the tourist destinations, Kayangan Api needs to be intensively developed towards optimal utilization, while still paying attention to the impact of tourism activities on the environment. Through the analysis of the Regional Carrying Capacity (DDK) it is known that the Kayangan Api tourist attraction has a carrying capacity that can and still needs to be developed. This includes its function for religious ritual activities and traditions of surrounding communities, as well as tourism objects with various other attractions. Through IFAS and EFAS technique SWOT analysis, all indicator scores occupy quadrant I which means that development activities can be carried out maximally through internal strengths and various opportunities arising from the external. The potential is in the form of the utilization of tourist attractions, namely the existence of natural gas and fire sources. The condition of environmental preservation in the form of protected forests can also be used as an identity or a special attraction, especially for the convenience of visitors. The pattern of development carried out primarily leads to the use of the area around the protected forest but does not change or damage the function of the protected forest. The development carried out requires a planning phase in the form of government consolidation, tourism management and the community and the determination of solutions as part of the planning and evaluation activities.

\section{REFERENCES}

[1] United Nation World Tourism Organization (UNWTO). 2018. UNWTO Annual Report 2017, Madrid, DOI https://doi.org/10.18111/9789284419807

[2] United Nation World Tourism Organization. 2019. International Tourism Highlights, 2019 Edition, UNWTO, Madrid, DOI: https://doi.org/10.18111/9789284421152.

[3] Kementrian Pariwisata. 2018. Rencana strategis 2018-2019 Kementrian Pariwisata. Jakarta. Kementrian Pariwisata Republik Indonesia

[4] Alamsjah, Iqbal. 2016. Paparan Kementerian Pariwisata RI Untuk Kidi Ke-6 2016. Yogyakarta: Wonderful Indonesia - Kepala Biro Hukum dan Komunikasi Publik, Kemenpar RI. Vol 6: 5

[5] Sabon, V. L. et al (2018). Strategi Peningkatan Kinerja Sektor Parawisata Indonesia Pada Asean Economic Community. Esensi: Jurnal Bisnis dan Manajemen. Vo.8 (2): 163 - 176. doi: 10.15408/ess.v8i2.5928.

[6] Sri, A. A. P. (2013). Faktor-Faktor Yang Memotivasi Perempuan Sebagai Pengelola Pondok Wisata Di Kelurahan Ubud, Kabupaten Gianyar. Jurnal Analisis Pariwisata. Vol. 13 (1)

[7] Pradipta et al. 2017. Peran Dinas Kebudayaan dan Pariwisata dalam Pengembangan Objek Wisata (Studi Pada Pengembangan Obyek Wisata Kayangan Api oleh Dinas Kebudayaan dan Pariwisata Kabupaten Bojonegoro). Jurnal Administrasi Bisnis. 52 (1).

[8] Angel V P N, .2017. Strategi Dinas Kebudayaan dan Pariwisata Dalam Kontribusi Peningkatan Pendapatan Asli Daerah di Kabupaten Bojonegoro. Jurnal FISIPOL. 2 (1).

[9] Bemmelen V. 1948. The Geology of Indonesia. Economic Geologi. Netherlands

[10] Pemkab Bojonegoro. 2018. Kunjungan wisata Bojonegoro Tahun : 2016 - 2017 - 1 Januari 2018. Bojonegoro. Situs resmi Pemerintah Kabupaten Bojonegoro: http://www.bojonegorokab.go.id

[11] Rangkuti, Freddy. 1997. Analisis SWOT Teknik Membedah Kasus Bisnis. Jakarta: Gramedia Pustaka Utama 
[12] Hardiyanto, Agus. Soejanto, Irwan. Berliant, Intan. 2018. Analisis Strategi Pembangunan Desa Wisata Di Sentra Pengrajin Keris. OPSI Jurnal Optimasi Sistem Industri

[13] Hanindya R. et al. Geokimia Daerah Panasbumi Gunung Pandan, Kabupaten Bojonegoro. Jurnal Geosains dan Teknologi. 1 (3).

[14] Yulianda, F. 2007. Ekowisata Bahari Sebagai Alternatif Pemanfaatan Sumberdaya Pesisir Berbasis Konservasi. Makalah Pada Seminar Sains
21 Februari 2007. Departemen Manajemen Sumberdaya Perairan, Fakultas Perikanan dan Ilmu Kelautan, IPB

[15] Oka A, Yoeti. 2008. Perencanaan dan Pengembangan Pariwisata. Balai Pustaka. Jakarta

[16] Edi S.2018. Pengembangan Objek Wisata Berbasis Analisis SWOT. Jurnal Spasial. 1 (1) 